\title{
Ossification of the superficial radial nerve causing pain: An Unusual Case of Progressive Osseous Heteroplasia
}

Ossification of the radial nerve, a case report

Key Words: nerve, congenital, flap, reconstruction

Authors:

1. Miles, Oliver; MD, BBiom, Surgical Resident St Vincent's Hospital Melbourne

75 Reid St, Fitzroy North, VIC,3068

Olivermiles91@gmail.com

+61433544293

2. Cabalag, Miguel; MBBS, FRACS

Plastic Surgery Consultant St Vincent's Hospital Melbourne

41 Victoria Parade, Fitzroy, VIC, 3065

miguel.cabalag@gmail.com

+61422602644

3. McCombe, David; MBBS, MD, FRACS.

Clinical Associate Professor, University of Melbourne

Plastic and Maxillofacial Surgery Dept, Royal Childrens Hospital, Melbourne

Plastic, Reconstructive and Hand Surgery Unit, St. Vincent's

Hospital, Melbourne

Victorian Hand Surgery Associates

Suite C37, 41 Victoria Parade, Fitzroy, 3065

+61394128820

david.mccombe@vhsa.com.au

Acknowledgements:

1. A/Prof Bruce Johnstone; MBBS, FRACS.

Consultant Plastic Surgeon Royal Childrens Hospital, Melbourne

Plastic and Maxillofacial Surgery Dept, Royal Childrens Hospital, Melbourne

2. Dr Preethi Mathew

MBBS BMedSc

Anatomical Pathology Registrar

St Vincent's Hospital Melbourne

preethi.mathew@svha.org.au

Corresponding Author:

This is the author manuscript accepted for publication and has undergone full peer review but has not been through the copyediting, typesetting, pagination and proofreading process, which may lead to differences between this version and the Version of Record. Please cite this article as doi: 10.1111/ans.15800

This article is protected by copyright. All rights reserved. 
1. Miles, Oliver; MD, BBiom, Surgical Resident St Vincent’s Hospital Melbourne

75 Reid St, Fitzroy North, VIC,3068

Olivermiles91@gmail.com

+61433544293

Progressive osseous heteroplasia $(\mathrm{POH})$ is a rare congenital genetic disorder, first described by Kaplan et al in 1994[1]. Patients experience heterotopic ossification (HO) from infancy, occurring within the skin and spreading deeper to involve the subcutis, connective tissues and muscle. $\mathrm{POH}$ presents as pain, ulceration or ankylosis of a joint due to deposition of bone within the skin or around a joint. As so few cases have been reported, the pathophysiology is poorly understood, however sporadic or inherited mutations inactivating GNAS1 on chromosome 20 are suggested to predispose mesenchymal stem cells (MSCs) to abnormal differentiation into osteoblast-like phenotypes[2, 3]. These MSCs then stimulate the process of intramembranous ossification, eventually progressing to HO. To the best of our knowledge, we present the first case of intractable pain secondary to ossification of the superficial branch of the radial nerve in a patient with long-standing $\mathrm{POH}$.

We report the case of a 24 year old male with recurrent $\mathrm{HO}$ secondary to $\mathrm{POH}$. He had received multiple procedures to excise problematic $\mathrm{HO}$, including four

This article is protected by copyright. All rights reserved. 
resections over his dominant right thumb and one over his right wrist.

Recurrence after resection for $\mathrm{POH}$ is high, with the risk increasing with the size of the involved lesion[2, 4, 5]. Recurrence of HO over the radial aspect of his right thumb resulted in pain and ankylosis of his $1^{\text {st }}$ metacarpo-phalangeal joint and carpo-metacarpal joint (Fig. 1), prompting the decision to explore and resect the recurrent cutaneous HO. Given the thin, scarred overlying skin, flap coverage to resurface the area following resection was required.

Resection was performed, resulting in a $17 \mathrm{x} 4 \mathrm{~cm}$ defect over the dorsoradial aspect of the thumb, involving nail plate, nail bed, skin, and any tissue containing HO including an ossified distal segment of the superficial radial nerve (SRN) (Fig. 2 and 3). This was most likely the major cause of his constant pain. A lateral arm flap was used for reconstruction to provide a thin fasciocutaneous flap as well as an acceptable donor site morbidity. The lateral cutaneous nerve of arm within the flap was coapted to the remnant of proximal SRN to both provide a sensate flap as well as help prevent a symptomatic neuroma. The post-operative recovery was uncomplicated and the patient was discharged day three postoperatively.

At last follow-up 12 weeks post-operatively, the flap was well healed and the patient had no pain, having returned to full work duties.

This article is protected by copyright. All rights reserved. 
The natural course of POH involves progression of cutaneous macular lesions from infancy, developing into ossified plaques and eventually forming painful ulcers and ankylosed joints. Hemimelic distribution of $\mathrm{HO}$, as experienced in our patient, may suggest a loss of heterozygosity of GNAS1 in progenitor cells during embryological development, explaining the often mosaic deposition of $\mathrm{HO}[2,6]$. Although limited long-term follow-up of $\mathrm{POH}$ is published, it is suggested that progression of the disease is rapid in infancy and childhood, however slows and stabilises into adolescence and adulthood.

Given the lack of reliable curative approaches to the management of $\mathrm{POH}$, treatment has mainly focused upon managing symptoms and avoiding inciting events for HO[7, 8]. Surgery has largely been ineffective with recurrence being the probable outcome in reported series[2]. For non-genetic HO, surgical monotherapy also lacks efficacy, however adjuvant therapy with NSAIDs and radiotherapy reduces the rate of recurrence[9]. Adjuvant measures have been trialled with surgery for one case of POH but recurrence occurred within two months[4]. Flap coverage of resection sites for $\mathrm{HO}$ has been used effectively for a case of severe HO secondary to trauma and spinal cord injury[8].

Despite the previously failed cases of surgically managed $\mathrm{POH}$, the utility of resection and flap coverage may demonstrate a new technique for managing this complicated condition. Using tissue from a different anatomical area, albeit from

This article is protected by copyright. All rights reserved. 
the ipsilateral effected limb, brings MSCs from a zone that may be spared of genetic predisposition to osteoblast-like differentiation, in keeping with the mosaic unilateral distribution of the disease. The slowed progression of $\mathrm{POH}$ with age deems adults as better surgical candidates who are less prone to recurrence. Our patient's last operation was eight years prior to receiving this latest resection and lateral arm flap.

Further follow-up will determine the long-term outcomes of this management, however skin excision and resurfacing may present a viable treatment for $\mathrm{POH}$ in adult patients with stable disease. Importantly, this case report highlights an often overlooked diagnosis of an ossified cutaneous nerve causing pain, which should be considered in patients with $\mathrm{POH}$.

Keywords:

Nerve, congenital, flap, reconstruction

References:

1. Kaplan, F.S., et al., Progressive osseous heteroplasia: a distinct developmental disorder of heterotopic ossification. Two new case reports

This article is protected by copyright. All rights reserved. 
and follow-up of three previously reported cases. J Bone Joint Surg Am, 1994. 76(3): p. 425-36.

2. Seror, R., C. Job-Deslandre, and A. Kahan, Progressive osseous heteroplasia: A rare case of late onset [2]. Rheumatology, 2007. 46(4): p. 716-717.

3. Job-Deslandre, C., Inherited ossifying diseases. Joint Bone Spine, 2004. 71(2): p. 98-101.

4. Athanasou, N.A., et al., Progressive osseous heteroplasia: a case report. Bone, 1994. 15(5): p. 471-5.

5. Kaplan, F.S. and E.M. Shore, Progressive osseous heteroplasia. J Bone Miner Res, 2000. 15(11): p. 2084-94.

6. Lin, M.H., et al., Progressive osseous heteroplasia, as an isolated entity or overlapping with Albright hereditary osteodystrophy. Journal of Pediatric Endocrinology and Metabolism, 2015. 28(7-8): p. 911-918.

7. Rodriguez-Jurado, R., F. Gonzalez-Crussi, and A.K. Poznanski, Progressive osseous heteroplasia, uncommon cause of soft tissue ossification: a case report and review of the literature. Pediatr Pathol Lab Med, 1995. 15(5): p. 813-27.

8. Gear, A.J., et al., Multifactorial refractory heterotopic ossification. Ann Plast Surg, 2004. 52(3): p. 319-24.

9. Lo, T.C., Radiation therapy for heterotopic ossification. Semin Radiat Oncol, 1999. 9(2): p. 163-70.

This article is protected by copyright. All rights reserved. 
Figure legend

Figure 1. Pre-operative X-ray showing diffuse heterotopic ossification throughout subcutaneous tissues of the right hand and wrist

Figure 2. Intra-operative view of superficial radial nerve with surrounding ossification (yellow arrow)

Figure 3. Histological specimen showing neural tissue (yellow arrow) within lamellated bone (blue arrow)

This article is protected by copyright. All rights reserved. 


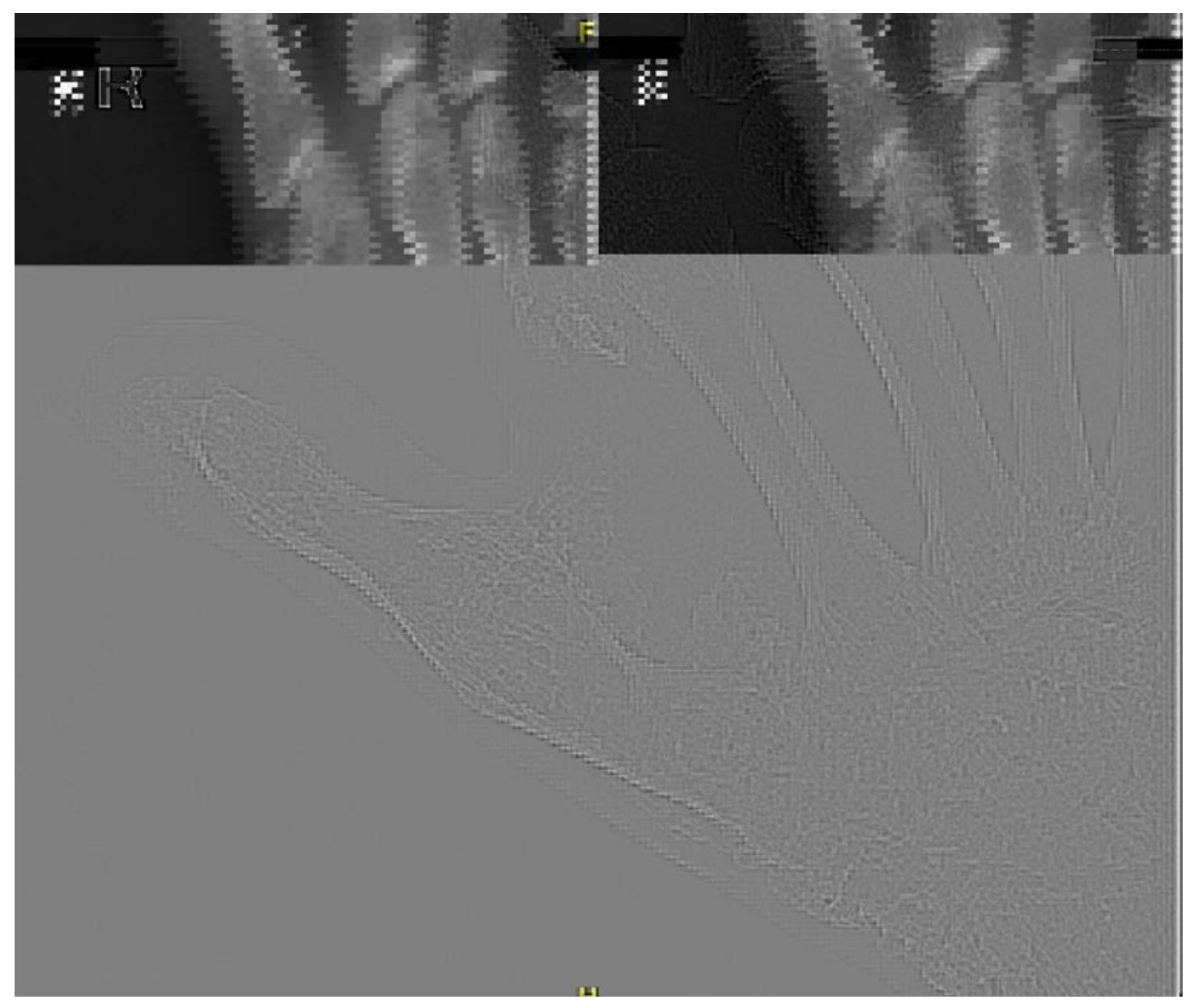

This article is protected by copyright. All rights reserved. 

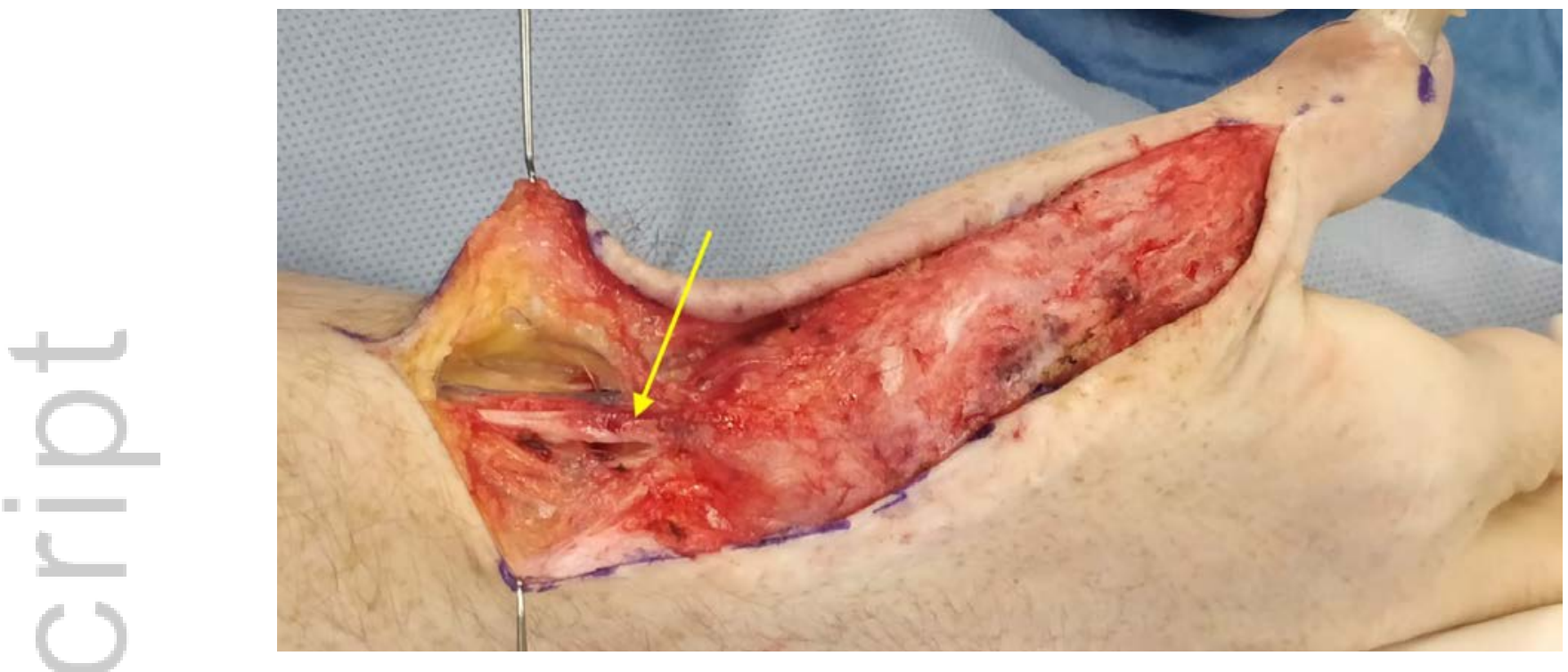

$\infty$
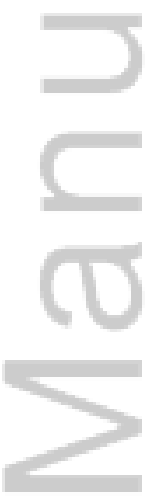

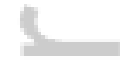
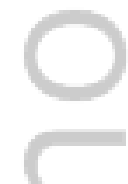

$=$

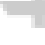

$+2$

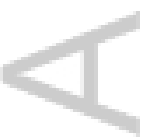

This article is protected by copyright. All rights reserved. 


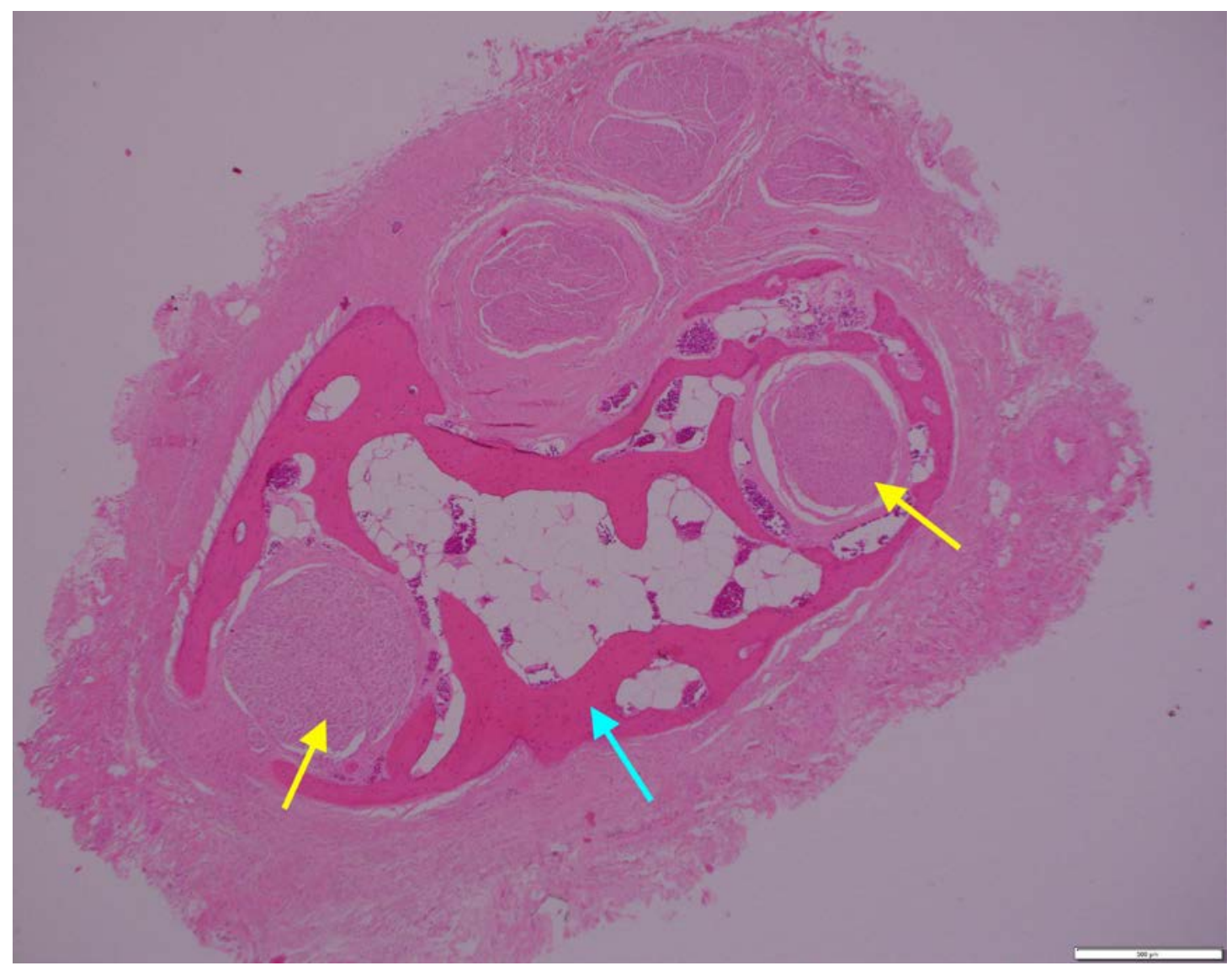

This article is protected by copyright. All rights reserved. 


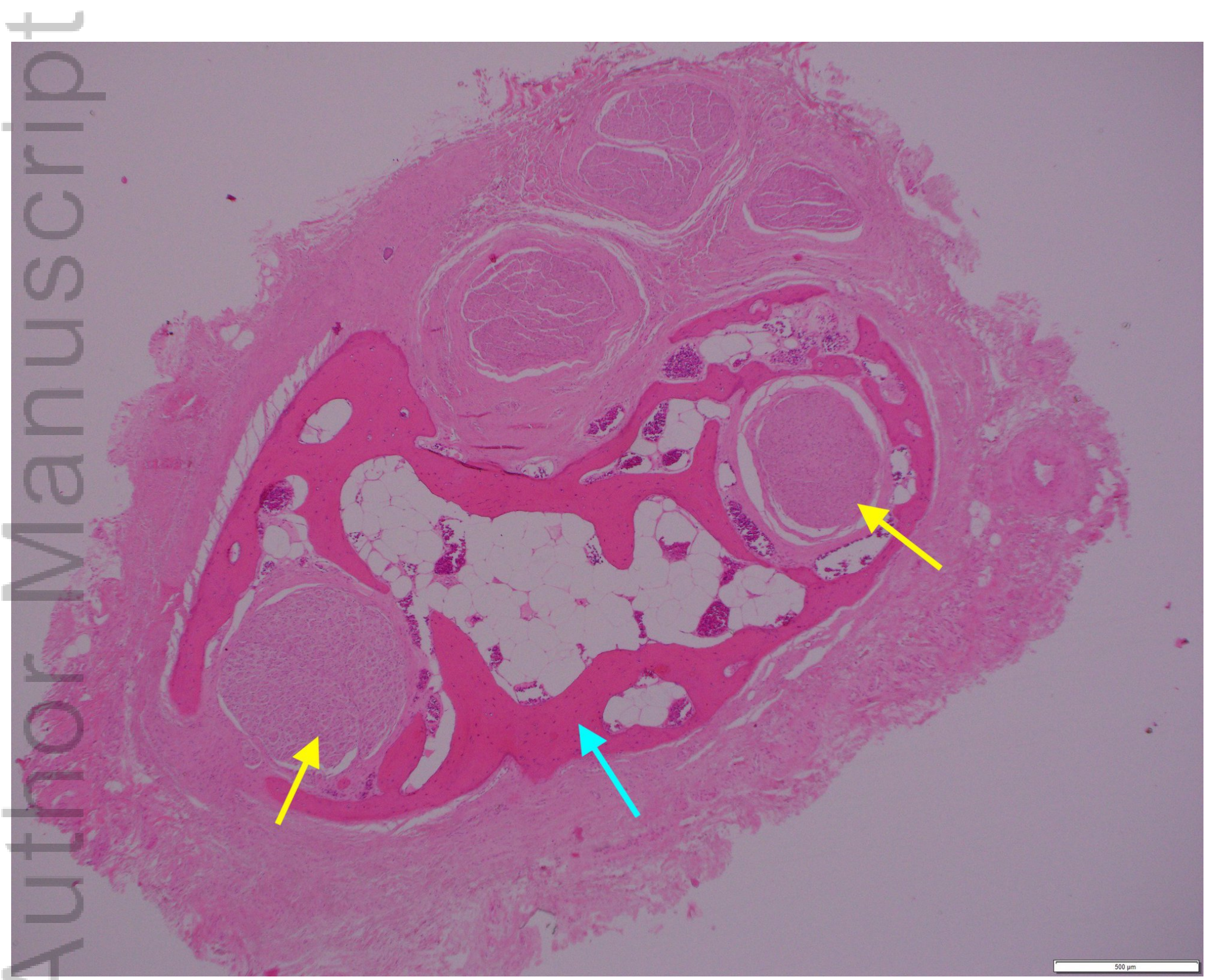

ANS_15800_Fig.3jpeg.jpg

This article is protected by copyright. All rights reserved. 


\section{Ossification of the superficial radial nerve causing pain: An Unusual Case of Progressive Osseous Heteroplasia}

Ossification of the radial nerve, a case report

Key Words: nerve, congenital, flap, reconstruction

Authors:

1. Miles, Oliver; MD, BBiom, Surgical Resident St Vincent's Hospital Melbourne

75 Reid St, Fitzroy North, VIC,3068

Olivermiles91@gmail.com

+61433544293

2. Cabalag, Miguel; MBBS, FRACS

Plastic Surgery Consultant St Vincent's Hospital Melbourne

41 Victoria Parade, Fitzroy, VIC, 3065

miguel.cabalag@gmail.com

+61422602644

3. McCombe, David; MBBS, MD, FRACS.

Clinical Associate Professor, University of Melbourne

Plastic and Maxillofacial Surgery Dept, Royal Childrens Hospital, Melbourne

Plastic, Reconstructive and Hand Surgery Unit, St. Vincent's

Hospital, Melbourne

Victorian Hand Surgery Associates

Suite C37, 41 Victoria Parade, Fitzroy, 3065

+61394128820

david.mccombe@vhsa.com.au

Acknowledgements:

1. A/Prof Bruce Johnstone; MBBS, FRACS.

Consultant Plastic Surgeon Royal Childrens Hospital, Melbourne

Plastic and Maxillofacial Surgery Dept, Royal Childrens Hospital, Melbourne

2. Dr Preethi Mathew

MBBS BMedSc

Anatomical Pathology Registrar

St Vincent's Hospital Melbourne

preethi.mathew@svha.org.au

Corresponding Author:

1. Miles, Oliver; MD, BBiom, Surgical Resident St Vincent's Hospital

Melbourne

75 Reid St, Fitzroy North, VIC,3068

Olivermiles91@gmail.com

+61433544293

This article is protected by copyright. All rights reserved. 


\section{University Library}

\section{- M M N E R VA A gateway to Melbourne's research publications}

Minerva Access is the Institutional Repository of The University of Melbourne

Author/s:

Miles, O;Cabalag, M;McCombe, D

Title:

Ossification of the superficial radial nerve causing pain: an unusual case of progressive osseous heteroplasia

Date:

2020-03-03

Citation:

Miles, O., Cabalag, M. \& McCombe, D. (2020). Ossification of the superficial radial nerve causing pain: an unusual case of progressive osseous heteroplasia. ANZ JOURNAL OF SURGERY, 90 (10), pp.2140-2142. https://doi.org/10.1111/ans.15800.

Persistent Link:

http://hdl.handle.net/11343/275505 